\title{
General Psychiatry CADASIL syndrome (cerebral autosomal dominant arteriopathy with subcortical infarcts and leukoencephalopathy) presenting as psychosis
}

\author{
Dheerendra Kumar Mishra, ${ }^{1}$ Aman Kishore, ${ }^{2}$ Vijay Niranjan ${ }^{3}$
}

To cite: Mishra DK, Kishore A, Niranjan V. CADASIL syndrome (cerebral autosomal dominant arteriopathy with subcortical infarcts and leukoencephalopathy) presenting as psychosis. General Psychiatry 2018;31:e100017. doi:10.1136/ gpsych-2018-100017

Received 19 September 2018 Revised 08 0ctober 2018 Accepted 12 October 2018

Check for updates

(c) Author(s) (or their employer(s)) 2018. Re-use permitted under CC BY-NC. No commercial re-use. See rights and permissions. Published by BMJ.

${ }^{1}$ Department of Psychiatry, Shyam Shah Medical College Rewa, Rewa, Madhya Pradesh, India

${ }^{2}$ Masik Aarogyashala Gwalior, Indore, Madhya Pradesh, India ${ }^{3}$ Department of Psychiatry, M. G. M. Medical College Indore, Indore, Madhya Pradesh, India

Correspondence to Dr Dheerendra Kumar Mishra; mdheerendra.ssmc@gmail.com

\section{ABSTRACT}

Cerebral autosomal dominant arteriopathy with subcortical infarct and leukoencephalopathy (CADASIL) is the most common monogenic form of cerebral small-vessel disease characterised by recurrent strokes. Behavioural disturbance also presents in a significant proportion of subjects as neurotic spectrum disorders and psychotic features are rarely reported. In this case report, we highlight a 32-year-old man with CADASIL syndrome, who had overt psychotic symptoms with neurological signs later on.

\section{INTRODUCTION}

Cerebral autosomal dominant arteriopathy with subcortical infarcts and leukoencephalopathy (CADASIL) is a rare genetic disorder due to the mutation in NOTCH-3 gene on chromosome $19 \mathrm{q} 12$, with autosomal dominant inheritance. ${ }^{12}$ Clinically, it most frequently presents as recurrent ischaemic episodes, cognitive deficits, dementia with gait disturbance, urinary incontinence, pseudobulbar palsy, migraine and epileptic seizures. Behavioural disturbances are seen in approximately $30 \%$ of the cases, ${ }^{3}$ with adjustment disorder, mood disorders, especially depression being the most frequent diagnosis. ${ }^{4}$ Psychotic symptoms in CADASIL syndrome are rarely reported in literature. Thus, we present a case of CADASIL with psychotic symptoms at a tertiary-care psychiatric hospital.

\section{CASE HISTORY}

A 32-year-old man presented with suspiciousness, fearfulness, odd ritualistic behaviour, decline in academic performance, self-care and social functioning and occasionally complaint of urinary and faecal incontinence, with symptoms starting from 14 years of age and being gradually progressive in the course. He had a history of seizure episodes at the age of 8 . For this reason he took antiepileptic medication for 4 years and since then there has been no recurrence of seizures. Futhermore, there was a family history of stroke in his father. The patient was treated with second-generation antipsychotics earlier, but there was no significant improvement in symptoms and also there was a history of developing extrapyramidal side effects with typical antipsychotics. His mental status examination revealed odd mannerisms, increased reaction time, retarded speech, shallow affect with decreased reactivity and delusion of persecution against the family member, with complete denial of illness by the patient. In addition, his neurological examination revealed ataxic gait while other parameters of physical examination were unremarkable. MRI brain imaging revealed confluent and discrete, fairly symmetric T2 hyperintense foci in the deep and subcortical white matter of the cerebral hemispheres, bilateral basal ganglia, brainstem, thalami and the subcortical white matter, suggesting the possibility of CADASIL syndrome. Thus, for confirmation, skin biopsy was performed which revealed granular osmophilic deposits in the basal lamina of a small blood vessel with degeneration and loss of smooth muscle cells under the electron microscope, as genetic testing was unavailable at our centre. The patient was given clozapine in view of his treatment history, which resulted in partial improvement of symptoms.

\section{DISCUSSION}

CADASIL is a rare genetic disorder, and the prevalence of CADASIL is unknown, but worldwide, pproximately 400 affected families 
have been reported. ${ }^{5}$ Notch protein family is composed of cell surface receptors that transduce signals between neighbouring cells. Notch3 is predominantly expressed in adult arterial smooth muscle cells in human and plays a critical role in maintaining the phenotypic stability of vascular smooth muscle cells. ${ }^{6}$ Common presentation is silent or clinically evident ischaemic strokes, migraine, seizure and cognitive impairment as described earlier. Neurotic symptoms are reported to be mainly associated with this syndrome. ${ }^{3}$ The exact pathophysiological mechanism underlying the association of psychotic symptoms with CADASIL syndrome is not clearly understood. One possible explanation is that multiple white matter infarcts particularly in the frontal region result in disruption of cortical-subcortical network which results in altered reality monitoring and genesis of psychotic symptoms. NNotch signalling pathways have a crucial role in neurodevelopment and altered Notch signalling is reported in schizophrenia, hence this may be a common dysfunction pathway between schizophrenia and CADASIL syndrome. ${ }^{7-9}$ Therefore, we want to make readers aware of this unique presentation of psychotic behavioural symptoms associated with CADASIL syndrome. A high index of suspicion is required when associated neurological features are found alongside unusual behavioural symptoms with inadequate response to management as usual. The targeted investigation is helpful for identifying this syndrome. Neuroimaging is helpful for identification of suggestible features. Although genetic testing is definitive for confirmation of diagnosis, as per previous literature skin biopsy yields high results with high sensitivity and specificity. ${ }^{10}$
Contributors DKM: collected data and summarised the case. AK: conceptualised and supervised the project. DKM, VN: contributed to drafting, revising and final version of the manuscript.

Funding The authors have not declared a specific grant for this research from any funding agency in the public, commercial or not-for-profit sectors.

Competing interests None declared.

Patient consent Parental/guardian consent obtained.

Provenance and peer review Not commissioned; externally peer reviewed.

Open access This is an open access article distributed in accordance with the Creative Commons Attribution Non Commercial (CC BY-NC 4.0) license, which permits others to distribute, remix, adapt, build upon this work non-commercially, and license their derivative works on different terms, provided the original work is properly cited and the use is non-commercial. See: http://creativecommons.org/ licenses/by-nc/4.0

\section{REFERENCES}

1 Buffon F, Porcher R, Hernandez K, et al. Cognitive profile in CADASIL. J Neurol Neurosurg Psychiatry 2006;77:175-80.

2 Scheid R, Preul C, Lincke T, et al. Correlation of cognitive status, MRI- and SPECT-imaging in CADASIL patients. Eur J Neurol 2006;13:363-70.

3 Dichgans M, Mayer M, Uttner I, et al. The phenotypic spectrum of CADASIL: clinical findings in 102 cases. Ann Neurol 1998;44:731-9.

4 Katsafouros K, Finokaliotis E, Rizos E, et al. CADASIL: case report and literature review. Psychiatriki 2008;19:21-7.

5 Toni-Uebari TK. Cerebral autosomal dominant arteriopathy with subcortical infarcts and leucoencephalopathy (CADASIL): a rare cause of dementia. Case Rep Child Meml Hosp Chic 2013;2013.bcr2012007285.

6 Wang T, Baron M, Trump D. An overview of Notch3 function in vascular smooth muscle cells. Prog Biophys Mol Biol 2008;96-499-509.

7 Talih FR. A probable case of peduncular hallucinosis secondary to a cerebral peduncular lesion successfully treated with an atypical antipsychotic. Innov Clin Neurosci 2013;10-28-31.

8 Ho CS, Mondry A. CADASIL presenting as schizophreniform organic psychosis. Gen Hosp Psychiatry 2015;37:273. e11-3.

9 McMurtray A, Tseng B, Diaz N, et al. Acute psychosis associated with subcortical stroke: comparison between basal ganglia and midbrain lesions. Case Rep Neurol Med 2014;2014:1-6.

10 Mayer M, Straube A, Bruening R, et al. Muscle and skin biopsies are a sensitive diagnostic tool in the diagnosis of CADASIL. J Neurol 1999;246:526-32.

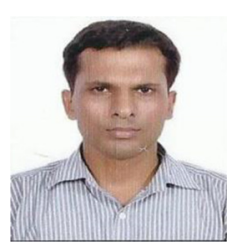

Dr. Dheerendra Kumar Mishra graduated (M.B.B.S.) from Shyam Shaha Medical College Rewa (M.P.) India, He did his post graduation (M.D. Psychiatry) in June 2017, and also receive Diplomat of National Board (Psychiatry) from National Board of Examination. He is currently working as Assistant professor in department of Psychiatry. His research interest includes Advance in psychiatric treatment, mood disorder, psychopharmacology and geriatric psychiatry. 